\title{
Policing Attorneys: Exclusion of Unethically Obtained Evidence
}

In zealously representing their clients, attorneys may be tempted to violate provisions of the rules of professional responsibility. ${ }^{1}$ In particular, an attorney may want to talk to an opposing party without obtaining the consent of the opposing party's counsel or without disclosing to the opposing party that he is an attorney. ${ }^{2}$ This comment argues that the current disciplinary apparatus to discourage such conduct is inadequate: it provides no meaningful disincentives to conduct that violates the rules of professional responsibility. The comment proposes as a solution to the problems created by courtroom use of evidence obtained by an attorney in violation of the rules of professional responsibility that courts exclude any evidence so obtained. In examining the rules and the ethical problems associated with evidence obtained by violating the rules, part I discusses the incentives lawyers have to ob-

2 "Rules of professional responsibility" and "rules" are used herein to refer to both sets of rules that the American Bar Association has promulgated for professional conduct: the Model Code of Professional Responsibility (1981) ("Model Code" or "Code") and the Model Rules of Professional Conduct (1983) ("Model Rules" or "Rules").

The Model Code consists of interrelated Canons, Ethical Considerations (ECs), and Disciplinary Rules (DRs). The Disciplinary Rules state required minimum standards for lawyers' conduct, the violation of which forms the basis for disciplinary action. See Model Code, Preliminary Statement. The Canons, Ethical Considerations, and Disciplinary Rules "define the type of ethical conduct that the public has a right to expect not only of lawyers but also of their non-professional employees and associates in all matters pertaining to professional employment." Id. The Code does not prescribe disciplinary procedures or penalties. Id.

The Model Rules consist of some rules that are imperative, defining proper conduct for purposes of professional discipline, and others that are permissive and define areas in which the lawyer has professional discretion. Model Rules Scope [1]. Failure to comply with a prohibition is a basis for invoking the disciplinary process. Model Rules Scope [5].

The Model Rules were promulgated as a result of criticisms of the Model Code. One criticism was that the Model Code's three-part format was confusing: the Code "tended to speak with two voices, creating conflict between its description of aspirations on the one hand and its proscription of certain conduct on the other; a conflict that never has been adequately resolved . . . " Robert J. Kutak, The Rules of Professional Conduct in an Era of Change, 29 Emory L. J. 889, 899 (1980) (footnote omitted) (suggesting that the Code's ethical considerations are inconsistent with its disciplinary rules).

2 For particular prohibitions, see Model Code DR 7-104(A)(1) (communication with other party without counsel's consent), 1-102(A)(4) (dishonest conduct); Model Rules, Rule 4.2 (communication with other party without counsel's consent), 4.1 (material false statements). 
tain evidence improperly, as well as the lack of effective deterrents. Part II assesses the costs and benefits of using an exclusionary rule as a solution to the problem of evidence obtained in violation of the rules and recommends the adoption of an exclusionary rule. Part III describes the implementation of such a rule, focusing on exceptions to and the scope of its use.

\section{The Tension Between the Rules of Professional Responsibility and ObTaININg Evidence}

This section examines how a lawyer's desire to uncover the strongest evidence for her client may conflict with her professional responsibilities. In particular, the section explores violations of the only two rules of professional responsibility that relate directly to obtaining evidence. Next, the section discusses how current enforcement of these rules is both ineffective and costly. It concludes with a review of the strong arguments for vigorous enforcement of the rules of professional responsibility that relate to obtaining evidence.

\section{A. Incentives to Violate the Rules: An Illustration}

Consider an ordinary products liability action, involving defective widgets, brought by an individual (Client) against a corporate defendant (Defendant). The defendant's counsel (Counsel) files responsive pleadings and motions. The plaintiff's attorney (Attorney) visits Defendant's employee (Inventor) who designed the widgets. Attorney states his name and asks Inventor questions about the widgets' design without informing Inventor that he is an attorney and is representing Client in the products liability case. Attorney also fails to inform Counsel or ask Counsel's permission to speak with Inventor. Inventor answers Attorney's questions, and Attorney tape records the conversation.

Attorney's actions save Attorney and Client time and money. Informally obtaining a statement from Inventor is far faster (and thus Attorney's fees are reduced) than taking a deposition with opposing counsel present to object to questions. Such informal interviews also are more likely to produce incriminating statements for two reasons. First, Inventor may be less guarded in his answers without Counsel present to warn him of the legal significance of his admissions. Second, without Counsel present, Attorney may more easily use tactics such as leading questions to trick or confuse Inventor. Thus, by obtaining this type of informal statement, Attorney not only saves time but also may gain some advantage at trial 
or in settlement negotiations.

Of course, in the process of obtaining Inventor's statement, Attorney has violated at least one, and possibly two, rules of professional responsibility. He has communicated with a witness (Inventor) without informing him of Attorney's relation to the litigation. ${ }^{3}$ And if Inventor has managerial responsibility, Attorney may have violated another rule by failing either to give notice to Counsel or to obtain Counsel's consent. ${ }^{4}$ Despite the violation of rules of professional responsibility, courts generally admit evidence obtained in a manner similar to that described above, rather than excluding it as proposed in this comment.

\section{B. Ineffective Enforcement of the Rules}

The legal system currently relies heavily upon state bar disciplinary proceedings to serve as a deterrent to attorney misconduct. Each state has its own disciplinary apparatus. ${ }^{6}$ In practically all states, violations of the rules of professional responsibility are supposed to be reported either to state grievance boards or to local or state bar associations that investigate the complaint and take appropriate action. But lawyers seldom complain to these disciplinary agencies about other attorneys' violations of professional

s "Even if the witness is an employee of the defendant, it is ethical for the attorney for the claimant to interview the witness so long as he or she practices no deception and informs the witness that he or she is the attorney for the claimant." American Bar Foundation, Annotated Code of Professional Responsibility 335 (1979) ("ABA Annotated Code"), quoting ABA Standing Committee on Ethics and Professional Responsibility, Formal Opinion 117 (Aug. 27, 1934) (emphasis added).

- Model Code DR 7-104(A)(1); Model Rules, Rule 4.2. For example, Model Code DR 7104 states:

(A) During the course of his representation of a client a lawyer shall not:

(1) Communicate or cause another to communicate on the subject of the representation with a party he knows to be represented by a lawyer in that matter unless he has the prior consent of the lawyer representing such other party or is authorized by law to do so.

Similarly, Model Rule 4.2 provides that "[i]n representing a client, a lawyer shall not communicate about the subject of the representation with a party the lawyer knows to be represented by another lawyer in the matter, unless the lawyer has the consent of the other lawyer or is authorized by law to do so."

see, e.g., Ross v. City of Geneva, 43 Ill. App. 3d 976, 985, 357 N.E.2d 829, 836-37 (1976): "While we, like plaintiff, are concerned with the practice of contacting members of the opposing class, which presents the opportunity to misrepresent the nature and effect of the class action and to encourage defection, we have found no Illinois rule or case law which would allow us to exclude such evidence. We therefore decline to exclude this evidence."

- See M. Bays Schoaf, State Disciplinary Enforcement Systems Structural Survey (1980). 
standards, ${ }^{7}$ and laymen often lack the knowledge to spot violations or do not know to whom to report them. ${ }^{8}$ Moreover, even if violations are reported, the disciplinary actions these agencies undertake are often ineffective and very costly. ${ }^{\circ}$

For example, during 1983, in the ten states (including the District of Columbia) having the largest numbers of practicing lawyers, at least 30,000 complaints resulted in the imposition of roughly 1,700 sanctions. ${ }^{10}$ The probability of any particular lawyer being sanctioned in a given year was thus quite low, ranging from 0.002 to 0.009 per lawyer. The administrative cost of the sanctions was very high, ranging from just over $\$ 6,000$ per sanction imposed in New York to almost $\$ 24,000$ per sanction in California. ${ }^{11}$ More specifically, in California, Illinois, Michigan, and New York City during 1974 and 1975, between 91 and 97 percent of all complaints received were dismissed without investigation. ${ }^{12}$

These figures reveal a serious problem, particularly in the area of administrative costs, but they may not reflect the full extent of the problem. Many experts believe that actual incidents of attorney misconduct are significantly underreported, ${ }^{13}$ though evidence

7 ABA Special Comm. on Evaluation of Disciplinary Enforcement, Problems and Recommendations in Disciplinary Enforcement 167-68 (1970) ("1970 ABA Report"). Attorneys and judges who observe misconduct often do not regularly report it. F. Raymond Marks and Darlene Cathcart, Discipline Within the Legal Profession, in Michael Davis and Frederick A. Elliston, eds., Ethics and the Legal Profession 62, 72 (1986).

B One professor summarized the problem: "Misconduct is rarely perceived. If perceived, it is not reported. If reported, it is not investigated. If investigated, violations are not found. If found, they are excused. If they are not excused, penalties are light." Richard L. Abel, Why Does the ABA Promulgate Ethical Rules?, 59 Tex. L. Rev. 639, 648 (1981) (footnotes omitted).

- For charges that the disciplinary procedures are inadequate because they are controlled by members of the bar, and that the process is decentralized and overly concerned with protecting the "unjustly accused lawyer," see Marks and Cathcart, Discipline Within the Legal Profession, in Davis and Elliston, eds., Ethics at 72-73 (cited in note 7).

10 Those jurisdictions are, in decreasing order of lawyer population: California, New York, Illinois, Texas, the District of Columbia, Ohio, Florida, Pennsylvania, Massachusetts, and New Jersey. Approximately 411,000 lawyers practice in those jurisdictions. Standing Comm. on Professional Discipline and the American Bar Association Center for Professional Responsibility, Statistical Report Re: Expense, Case Volume, and Staffing of Lawyer Disciplinary Enforcement in State Jurisdictions During 1983, Chart I (Sept. 1984) ("1983 ABA Statistical Report").

11 Eric H. Steele and Raymond T. Nimmer, Lawyers, Clients and Professional Regulation, 1976 Amer. Bar Found. Research J. 917, 982.

121983 ABA Statistical Report at Chart I (number of sanctions), Chart III (disciplinary budget) (cited in note 10).

${ }_{13}$ See F. Raymond Marks and Darlene Cathcart, Discipline Within the Legal Profession: Is it Self-Regulation?, 1974 U. III. L. Forum 193, 207 (1974). Consider also Abel, 59 Tex. L. Rev. at 648 (cited in note 8); Steele and Nimmer, 1976 Amer. Bar Found. Research J. at $\mathbf{9 4 6}$ (cited in note 11) (noting variations among jurisdictions in number of reports per 
for this view is wholly anecdotal..$^{14}$

Even for those violations that are reported, most experts agree that current disciplinary methods are ineffective. For example, the ABA Committee on Evaluation of Disciplinary Enforcement reported that " $[w]$ ith few exceptions, the prevailing attitude of lawyers toward disciplinary enforcement ranges from apathy to outright hostility. Disciplinary action is practically nonexistent in many jurisdictions; practices and procedures are antiquated; many disciplinary agencies have little power to take effective steps against malefactors."1s As a result, only the most egregious ethics violations are investigated and punished. ${ }^{16}$ Even where disciplinary agencies have the will and the authority, they frequently fail to take action because they lack the necessary funds. ${ }^{17}$

Whatever the reason, enforcement of the rules of professional responsibility is lax. One way to attack the problem of ineffective enforcement is to provide more money for disciplinary agencies. In the ten states with the highest populations of lawyers, a positive correlation exists between disciplinary expenditures per lawyer and the frequency with which sanctions are imposed. ${ }^{18}$ This suggests that some instances of misbehavior may be going unpunished: if the level of expenditure were sufficient to allow detection and prosecution of every violation of the rules of professional responsibility, one would expect to find no positive correlation between expenditures per lawyer and frequency of sanctions. ${ }^{19}$

lawyer).

14 American Bar Association Commission on Professionalism, " ... In the Spirit of Public Service": A Blueprint for the Rekindling of Lawyer Professionalism 65 \& n.120 (1986) (citing testimony by the United States Attorney for the Northern District of Mllinois and the Administrator of the Illinois Attorney Registration and Disciplinary Commission).

$151970 \mathrm{ABA}$ Report at 1 (cited in note 7), reprinted in Geoffrey C. Hazard and Deborah L. Rhode, The Legal Profession: Responsibility and Regulation 428 (1985).

16 Deborah L. Rhode, Why the ABA Bothers: A Functional Perspective on Professional Codes, 59 Tex. L. Rev. 689, 718 (1981). At least until recently, the few cases that resulted in disciplinary proceedings usually involved unfair professional competition, criminal misconduct, gross incompetence, or stealing a client's funds, and they usually resulted in only mild sanctions. See Geoffrey C. Hazard, Ethics in the Practice of Law 59 (1978).

171970 ABA Report at 2 (cited in note 7) ("[S]tate disciplinary agencies are undermanned and underfinanced, many having no staff whatever for the investigation or prosecution of complaints.").

1s 1983 ABA Statistical Report at Chart I (number of lawyers and sanctions), Chart III (disciplinary budget) (cited in note 10). For example, during 1983, Florida spent about $\$ 68$ per licensed lawyer on disciplinary investigation and procedures and imposed .009 sanctions per lawyer. At the other extreme, the District of Columbia spent about $\$ 27$ per lawyer and imposed fewer than .002 sanctions per lawyer. Id. at Chart I.

1" Indeed, in theory, if sufficient funds were available to make detection and prosecution of each violation a certainty, the resulting deterrent effect might actually lead to a 
However, the solution to curbing attorney misconduct is not simply to provide more funding under the current enforcement system. First, it would be very expensive, and thus perhaps politically unpalatable, for states to allocate enough additional funds to enforcement to curtail attorney misconduct substantially. Second, while more funding may improve the effectiveness of disciplinary proceedings, it will do little to ensure that more violations are reported. More frequent imposition of sanctions will not necessarily enhance the incentives or abilities of attorneys or laypersons to report rule violations, since they will gain nothing from the sanctions.

As long as disciplinary proceedings are separate from the underlying legal proceedings, violations are not likely to be reported because few incentives exist for anyone, especially other attorneys, to look for and to report violations. An opposing attorney reporting a violation derives no benefits for himself or his client, since no award of damages will result. Further, there are significant costs to reporting: a reporting attorney will incur the antagonism of the attorney against whom he reports and with whom he may have to work in the future. And to report violations by one's colleague may undermine general camaraderie in the profession and may itself be stigmatizing, especially among lawyers practicing in a particular location or specialty.

Further, the primary purpose of disciplinary proceedings is not to punish improper conduct. "They are not for the purpose of punishment, but rather seek to determine the fitness of an officer of the court to continue in that capacity. . . ."20 Rarely has a state disbarred or suspended an attorney for the kinds of violations of the rules of professional responsibility at issue here. Such serious sanctions are directed mostly at attorneys who disserve their clients (through negligence or misappropriation of funds) or who are convicted of criminal behavior. ${ }^{21}$ Thus, the threat of disciplinary

reduction in the level of rule violations, and thus in the number of sanctions because attorneys would choose to avoid violating the rules out of fear of prosecution. This clearly has not occurred yet. Therefore, the need for less costly deterrents, such as the rule proposed in this comment, is still pressing. For raw data, see id. at Chart I, Chart III.

${ }^{20}$ ABA Standards For Lawyer Discipline and Disability Proceedings, Standard 1.1 Commentary (1983) ("ABA Discipline Standards"), citing In re Echeles, 430 F.2d 347, 349 (7th Cir. 1970).

${ }^{21}$ For example, in the 1960s and 1970s in six large states and New York City, offenses against clients accounted for between 33 and 75 percent of serious public disciplinary sanctions, criminal convictions for between 10 and 28 percent. See Steele and Nimmer, 1976 Amer. Bar Found. Research J. at 995 (cited in note 11) (statistics for California, Florida, Michigan, New York, New York City, Texas, and Wisconsin). 
proceedings appears to provide an inadequate deterrent to attorney misconduct of the type addressed in this comment. ${ }^{22}$

Better enforcement is desirable. There are significant benefits inherent in the rules of professional responsibility. ${ }^{23}$ Moreover, without effective enforcement, attorneys who follow the rules may be placed at a disadvantage compared to attorneys who violate the rules without fear of being punished. ${ }^{24}$

\section{Rationales for the Rules}

1. The prohibition against communication without consent of counsel. Several benefits result from the rule prohibiting communication with a represented party without his attorney's presence or consent. First, the prohibition against communication protects the integrity of attorney-client relationships because it prevents one attorney from interfering with an opposing party's relationship with his counsel. While the rule may be attacked by cynics as an example of how members of the legal profession protect their own economic interests, ${ }^{25}$ its primary purpose is to protect the interests of clients, who might otherwise fall prey to cajoling opposing counsel whose interests are directly opposed to those of the clients. This protection is vital in the early stages of litigation, when a client least understands his case. In criminal prosecutions, for example, Supreme Court decisions have extended defendants' right to counsel under the sixth amendment and the due process clause to pretrial stages, reasoning that a defendant needs the "guiding hand of counsel at every step in the proceedings

${ }^{22}$ A judge imposing the exclusionary sanction on an attorney should nevertheless report the attorney to the appropriate disciplinary authority. See ABA Standing Comm. on Professional Discipline and the Center for Professional Responsibility, The Judicial Response to Lawyer Misconduct V.3 (1984).

${ }^{23}$ See part I-C below.

14 [W] hether one is likely to be caught for violating an ethical standard says nothing about the merit of the standard. However, if the low probability of punishment means that many lawyers will violate the standard, the standard becomes even more difficult for the honest lawyer to follow, for by doing so he may be forfeiting a significant advantage for his client to others who do not follow the rules.

James J. White, Machiavelli and the Bar: Ethical Limitations on Lying in Negotiation, 1980 Amer. Bar Found. Research J. 926, 927.

${ }^{25}$ Some would argue that the rule's primary purpose is to enlarge the market for attorneys' services and to protect them from competition once they have secured a client. Attacks on various ethical rules as devices for obtaining and retaining market power have been frequent. See, e.g., Bates v. State Bar, 433 U.S. 350, 377-78 (1977) (striking down a state bar prohibition on attorney advertising as violating attorneys' first amendment rights to engage in commercial speech); Philip Shuchman, Ethics and Legal Ethics: The Propriety of the Canons as a Group Moral Code, 37 Geo. Wash. L. Rev. 244, 250-56, 268 (1968). 
against him." ${ }^{26}$ And, as demonstrated in Gideon v. Wainwright, ${ }^{27}$ the courts have come to view the lawyer as a necessity in protecting a criminal defendant's rights.

In civil cases, although the sixth amendment does not apply, the right to choose one's own counsel has nevertheless been recognized, ${ }^{28}$ and the attorney-client relationship is protected, for example, by the attorney-client privilege. The prohibition on communication operates in part to protect the attorney-client relationship, just as the sixth amendment (in criminal cases) and the attorneyclient privilege (in all cases) protects this relationship.

The rule against communication is particularly compelling where a party has chosen to have counsel in a criminal or civil case, because the party's decision to retain counsel reflects his judgment that a lawyer will be both helpful and protective and that he is unable without such aid to best protect his interests. Of course, if a client decides that he would rather save the attorneys' fees, or that he can best represent his interests himself, he is free to dismiss his attorney and deal directly with opposing counsel. But "[o]nce a person has enlisted the aid of a lawyer, he is entitled to all the benefits that flow from that choice."29

The rule against communication has greater significance when one considers that, at least in criminal cases, defendants have a right to the effective assistance of counsel. Just as a criminal defendant is denied effective assistance of counsel if subjected to post-indictment interrogation without an attorney, ${ }^{\text {so }}$ so too may a

26 Powell v. Alabama, 287 U.S. 45, 68-69 (1932). See U.S. Const. amend. VI; Coleman v. Alabama, 399 U.S. 1, 9 (1970):

[T] he guiding hand of counsel at the preliminary hearing is essential to protect the indigent accused against an erroneous or improper prosecution. First, the lawyer's skilled examination and cross-examination of witnesses may expose fatal weaknesses in the state's case. . . . [T] he skilled interrogation of witnesses by an experienced lawyer can fashion a vital impeachment tool for use in cross-examination . . . or preserve testimony ... of a witness who does not appear at the trial. . . . [T] rained counsel can more effectively discover the case the State has against his client and make possible the preparation of a proper defense ....

${ }_{27} 372$ U.S. 335, 344 (1963): "That government hires lawyers to prosecute and defendants who have the money hire lawyers to defend are the strongest indications of the widespread belief that lawyers in criminal courts are necessities, not luxuries. The right of one charged with crime to counsel may not be deemed fundamental and essential to fair trials in some countries, but it is in ours."

${ }^{28}$ See, e.g., In re American Cable Publications, Inc., 768 F.2d 1194, 1196-97 (10th Cir. 1985); In re Northern Dist. of Cal., Dalkon Shield, etc., 693 F.2d 847, 851 (9th Cir. 1982).

39 Lewis Kurlantzik, The Prohibition on Communication with an Adverse Party, 51 Conn. Bar J. 136, 151 (1977).

so Massiah v. United States, 377 U.S. 201, 204-05 (1963) (the Constitution requires "effective" representation of counsel, which includes representation during the interrogation of 
party to a civil case be deprived of effective legal assistance if he is interviewed prior to trial without his attorney present. First, the attorney will be unable to advise his client at the time and prevent him from injuring his case, for example, by revealing information protected by a privilege. Second, the attorney will be unable to prevent the opposing attorney from using improper tactics (such as leading questions) and will not be able to witness whether the opposing attorney has misled the client. If the attorney is present, he may be able either to prevent such behavior or later to demonstrate that such behavior occurred.32 Thus, the prohibition against communication protects the attorney's ability to champion his client's cause effectively.

The benefits of counsel described above can be summarized by characterizing counsel's role as that of a shield protecting his client throughout the litigation and negotiation processes. ${ }^{32}$ Counsel prevents his client from falling into traps laid by opposing counsel ${ }^{\text {ss }}$ and guides his client through the complicated technicalities of the law's procedural system. ${ }^{34}$ The layman client is in a poor position to analyze his case or to evaluate meaningfully what the opposing counsel tells him. ${ }^{35}$

Further, the attorney takes responsibility for many details of the litigation so that the client need not pay constant attention to the lawsuit. This serves another goal of the legal system-to ensure that lawsuits are not too onerous or time-consuming for parties to continue in their normal businesses. Accordingly, the attorney takes over most of the burdens of the lawsuit, and part of his role is to protect the client from unnecessary harassment by the opposing party. ${ }^{36}$

an indicted defendant, not just during his trial).

s2 See United States v. Wade, 388 U.S. 218, 237 (1967) (attorney presence at "lineup" identification procedure necessary to protect against suggestibility of witnesses).

32 The rationale for the prohibition on communication is that the legal system "functions best when persons in need of legal advice or assistance are represented by their own counsel." American Bar Foundation, Annotated Code of Professional Responsibility EC 7-18 at 332 (1979).

ss See, e.g., United States v. Ash, 413 U.S. 300, 317 (1973), quoting United States v. Bennett, 409 F.2d 888 (2d Cir. 1969) ("[C]ounsel is . . . to be provided to prevent the defendant himself from falling into traps devised by a lawyer on the other side. . . .").

st See e.g., Ash, 413 U.S. at 307.

ss See, e.g., Kurlantzik, 51 Conn. Bar J. at 141 (cited in note 29). In light of this imbalance, "the notion of an 'informed' waiver as an exemption to the communication rule appears as at best problematic." Id. at $141 \mathrm{n} .14$.

30 The attorney is helped in this role by Fed. Rule Civil Proc. 26(c), which provides for protective orders and includes among its express purposes the protection of a "party or person from annoyance, embarrassment, oppression or undue burden or expense." Seattle 
The prohibition against communication also helps to prevent attorneys from misleading opposing parties with impunity. Allowing communication would make it virtually impossible to police misleading behavior by attorneys because often there would be no witnesses other than the party who has been misled, who is a poor witness. ${ }^{37}$ Since the lawyer may be unlikely to deal with an opposing lay party in any other litigation, and since the opposing party may have infrequent litigation needs, the "possible diminution in the lawyer's reputation for fair dealing will probably not be a major constraint on his behavior."38 The adversarial relationship also lacks "reversibility"- that is, the roles of lawyer and opposing layman are not likely ever to be reversed-so incentives for fair dealing are reduced. ${ }^{39}$

Since some prohibited communications are not harmful, and since they may uncover information material to the dispute, the court might try to identify in each case whether the communication was helpful or harmful, to avoid tossing out the good with the bad. But a prophylactic rule forbidding communications entirely is preferable to such case-by-case determinations. Detection of attorney misbehavior that takes advantage of opposing parties is difficult and imperfect. Thus, the likelihood of abuse would be higher under the case-by-case approach:

To keep clear of the need to make difficult hindsight judgments of fairness in every situation and to remove, or at least

Times Co. v. Rhinehart, 467 U.S. 20, 35 n.21 (1984).

Courts also award attorneys' fees to discourage actions that are vexatious, malicious, or in bad faith, or that are taken for oppressive reasons. Copeland v. Martinez, 603 F.2d 981, 984 (D.C. Cir. 1979); Equal Emp. Opportunity Comm'n v. Datapoint Corp., 457 F. Supp. 62 , 69 (W.D. Tex. 1978). For the same reason, "[d]epositions are scheduled at times and places most convenient to those involved." Seattle Times, 467 U.S. at 33 n.19. Under our legal system, lawsuits are not supposed to consume the litigants, as did Jarndyce v. Jarndyce in Dickens's Bleak House at 72-73 (Morton Zabel, ed. 1956):

"The Lawyers have twisted it into such a state of bedevilment that the original merits of the case have long disappeared from the face of the earth. It's about a Will, and the trusts under a Will-or it was, once. It's about nothing but Costs, now. We are always appearing, and disappearing, and swearing, and interrogating, and filing, and crossfiling, and arguing, and sealing, and motioning, and referring, and reporting, and revolving about the Lord Chancellor and all his satellites, and equitably waltzing ourselves off to dusty death, about Costs. . . . And thus, through years and years, and lives and lives, everything goes on, constantly beginning over and over again, and nothing ever ends. And we can't get out of the suit on any terms, for we are made parties to it, and must be parties to it, whether we like it or not."

37 Kurlantzik, 51 Conn. Bar J. at 141 (cited in note 29) ("[T]he layman [himself] may well not detect or appreciate, for some time, the fact that he has been misguided.").

${ }^{38}$ Id. at 140.

ss Id. 
reduce, the risk of overreaching, we pay this price [i.e., prevention of communications which would produce a perfectly fair resolution of a dispute] for a broad, prophylactic rule. It seems a tolerable price, particularly in light of the fact that on balance what can be said for permitting communications does not appear to be very substantial. ${ }^{40}$

In addition to the other costs of having attorneys act as intermediaries between parties, ${ }^{41}$ there is a possibility that the court's truth-finding function will be frustrated because the opposing attorney and his client may prevent the acquisition of material information that would have come out in the prohibited communications. However, as discussed in part II-C below, the prohibited communications may be of questionable reliability. Thus, the benefits of a broad rule against communication outweigh its costs.

2. The prohibition against misrepresentation. Some of the aforementioned rationales in favor of the prohibition against communications also apply to the prohibition against misrepresentation and misleading behavior by attorneys. The desire for a legal system that is as unburdensome and efficient as possible is also frustrated by misrepresentation and misleading behavior. The more such practices go unchecked, the more people will fear that resorting to the legal system will result in unpleasant and possibly detrimental encounters with unscrupulous attorneys. The rules against misrepresentation and misleading behavior preserve public confidence in the legal system, assuring that individuals will not be discouraged from bringing valid suits or defending against invalid ones.

The rule against misrepresentation of an attorney's relation to a case also helps to ensure that all parties are on fair notice as to the significance of their conversations. This generally will work to increase the accuracy of statements made in such conversations. Most people take greater care when speaking for the record. Responses induced by misrepresentation or trickery, on the other hand, are likely to be less precisely worded and hence may be less accurate, particularly when only one party's attorney asks questions and the opposing party's attorney has no opportunity to follow up and clarify the meaning of the responses. ${ }^{42}$ Moreover, if a

10 Id. at $143-44$.

11 These costs include the administrative costs and the agency costs of representation of litigants by attorneys. Id. at 154-55.

${ }^{42}$ This rationale parallels one of the rationales for exclusion of hearsay evidence. Hearsay evidence is excluded because out-of-court statements usually are not made with as high 
party has an inclination to lie, he may be more likely to suppress it and to tell the truth if he knows he is talking to a lawyer who is familiar with the case and who might turn his untruthfulness against him later. Of course, if a witness has something to hide, providing him with notice will enable him to be careful to speak so as to conceal his secret. Thus, the rule against misrepresentation clearly increases the likelihood of accurate memory, perception, and narration, while it is uncertain whether it increases or decreases the likelihood of sincerity. The relative importance of these concerns will vary from case to case. But on balance, despite some risk of insincerity, the prohibition against misrepresentation seems worthy of enforcement.

\section{Excluding Evidence Obtained In Violation of the Rules of Professional Responsibility}

This section first examines the power of federal and state courts to enforce the rules of professional responsibility by excluding evidence obtained in violation of them. Then, surveying the benefits from the courts' exercise of this power, the section suggests that adoption of such an exclusionary rule will serve the ends of deterrence and judicial integrity, the same goals identified by the Supreme Court at various times to justify the use of exclusionary rules in fourth, fifth, and sixth amendment cases..$^{43}$ In addition,

a level of seriousness and accuracy as those made in court, where the solemnity of the proceedings can be impressed on the witness and the opposing side may pose questions to clarify the meaning of responses. See Chambers v. Mississippi, 410 U.S. 284, 298 (1973).

43 The Supreme Court has recognized exclusion as a valid (indeed mandatory) judicial remedy for police violations of the fourth, fifth, and sixth amendments' protections with respect to search and seizure, self-incrimination, and the right to counsel. See, e.g., Mapp v. Ohio, 367 U.S. 643 (1961) (search and seizure); Miranda v. Arizona, 384 U.S. 436 (1966) (confession obtained in violation of right against self-incrimination); Wade, 388 U.S. at 218 (identification of defendant by witness in violation of right to counsel).

A common argument for such rules has been that courts would sanction constitutional violations if they countenanced use of such illegally-obtained evidence. In Weeks v. United States, 232 U.S. 383 (1914), the Court adopted an exclusionary rule for federal criminal proceedings, holding that papers obtained without a warrant from the defendant's home by federal officers could not be used at trial and should have been returned to the defendant. The Court stated: "To sanction such proceedings would be to affirm by judicial decision a manifest neglect if not an open defiance of the prohibitions of the Constitution, intended for the protection of the people against such unauthorized action." 232 U.S. at 394. For other cases justifying the exclusionary rule as a safeguard of judicial integrity, consider United States v. Janis, 428 U.S. 433, 458 n.35 (1976); United States v. Calandra, 414 U.S. 338, 35660, 363-64 (1973) (Brennan, J., dissenting); Terry v. Ohio, 392 U.S. 1, 12-13 (1968); Elkins v. United States, 364 U.S. 206, 222-23 (1960). On the other hand, several Supreme Court cases have suggested that the primary justification for the exclusionary rule is that it deters unlawful police conduct by eliminating any gains to be realized from it. See Calandra, 414 U.S. 
an exclusionary rule will facilitate policing of the rules of professional responsibility by the legal profession itself. This will reduce the frequency of attorney misconduct without increasing the already substantial administrative costs of the current system of disciplinary sanctions.

\section{A. The Power of Courts to Implement an Exclusionary Rule}

Exclusionary rules are an appropriate means of enforcing legal requirements or, as in this instance, creating behavioral incentives. Courts have adopted exclusionary sanctions to accomplish purposes having little or no relation to the truthfulness or probative value of the evidence involved. For example, in order to avoid creating disincentives to repair after an accident or injury has occurred, courts have excluded evidence of subsequent repairs when such evidence is offered to prove negligence or culpable conduct. ${ }^{44}$ As one court has explained: "The desirability of deterring improper conduct is a matter which a court can properly consider in exercising its discretion as to the exclusion of evidence."4s

Further, while violations of the rules of professional responsibility are handled primarily through the disciplinary apparatus, courts often use their powers to enforce certain provisions of these rules-particularly the provisions with respect to conflicts of interest and maintenance of client confidences. For example, courts frequently disqualify an attorney who attempts to represent a party

at 347; Janis, 428 U.S. at 446; Stone v. Powell, 428 U.S. 465, 486 (1976).

Recently, however, the Court has appeared increasingly dissatisfied with the exclusionary rule, at least in fourth amendment cases. See, e.g., Stone, 428 U.S. at 485 (significantly limiting habeas corpus review of fourth amendment claims) ("While courts, of course, must ever be concerned with preserving the integrity of the judicial process, this concern has limited force as a justification for the exclusion of highly probative evidence."); id. at 499 (Burger, C.J., concurring) (arguing that the "imperative of judicial integrity" has "not withstood analysis as more and more critical appraisals of the [exclusionary] rule's operation have appeared"). See also United States v. Leon, 468 U.S. 897, 913 (1984) (announcing exception to exclusionary rule when police rely on a warrant's validity in good faith).

Of course, any analogy to the exclusionary rules followed in criminal cases is imperfect. First, the benefits of exclusion where constitutional violations have occurred are clearly greater than in the professional responsibility context. Protection of fundamental rights enshrined in the Constitution would seem more important than enforcement of the rules of professional responsibility, and there is something particularly troubling about the state ratifying through its courts the illegal behavior of its law enforcement officials. On the other hand, the costs of exclusion are also greater in the context of criminal procedure, since application of the rule may result in acquittal of a guilty criminal. Therefore, some criticisms of the constitutional exclusionary rule may be less powerful in the context of professional responsibility. See note 102 and accompanying text below.

"Fed. Rule Evid. 407.

4s Kenyatta v. Kelly, 375 F. Supp. 1175, 1179 (E.D. Pa. 1974). 
opposing the attorney's former client in a matter "substantially related" to the former representation..$^{46}$ Courts have held that violations of any of a number of Canons of the Code of Professional Responsibility may serve as the basis of disqualification. ${ }^{47}$

However, although courts regularly have enforced many provisions of the Code of Professional Responsibility through judicial sanctions, they have rarely used sanctions to enforce the provision barring communications with opposing parties represented by counsel without notifying counsel ${ }^{48}$ or the provisions prohibiting attorney conduct involving dishonesty or misrepresentation. ${ }^{49} \mathrm{Ex}-$ cluding evidence obtained in violation of this part of the Code or the parallel provisions of the Rules would remedy this gap in enforcement.

1. State courts' power to exclude unethically obtained evidence. Most states have adopted the Model Code, although as of November, 1986, sixteen states had adopted the Model Rules. ${ }^{50}$ California has its own Rules of Professional Conduct. ${ }^{.1}$ In many states, the Code or Rules have been adopted as Rules of Court by the state's highest court ${ }^{52}$ or have been approved by that court..$^{53}$

${ }^{46}$ See, e.g., Trone v. Smith, 621 F.2d 994, 998 (9th Cir. 1980); Brennan's, Inc. v. Brennan's Restaurants, Inc., 590 F.2d 168, 171 (5th Cir. 1979); Hull v. Celanese Corp., 513 F.2d 568, 572 (2d Cir. 1975); Emle Industries, Inc. v. Patentex, Inc., 478 F.2d 562, 570-71 (2d Cir. 1973). The "substantial relation" test was first articulated by Judge Weinfeld in T.C. Theatre Corp v. Warner Bros. Pictures, 113 F. Supp. 266 (S.D. N.Y. 1953).

See also United States v. Snyder, 707 F.2d 139 (5th Cir. 1983) (holding that the professional responsibility rules require disqualification of an attorney indicted for the same crime as his client).

${ }^{17}$ See Model Code Canon 1 (maintaining the integrity and competence of the legal profession), Canon 4 (preserving confidences and secrets of a client), Canon 5 (exercising independent professional judgment), Canon 6 (representing a client competently), Canon 7 (representing a client zealously within the bounds of the law), and Canon 9 (avoiding even the appearance of professional impropriety). For cases approving disqualification, see Trone, 621 F.2d at 999 (citing all these canons); Emle Industries, 478 F.2d at 574 (citing Canon 4); Ex parte Taylor Coal Co., Inc., 401 So. 2d 1, 5-7 (Ala. 1981) (citing Canons 4 and 9); Snyder, 707 F.2d at 145 (citing Canon 9); Hull, 513 F.2d at 571 (citing Canon 9).

4 See Model Code DR 7-104.

to See id. at DR 1-102. A few federal courts have barred evidence obtained in violation of the rules of professional responsibility in criminal cases. See note 66 below.

so These states are Arizona, Arkansas, Connecticut, Delaware, Florida, Idaho, Maryland, Minnesota, Missouri, Montana, New Hampshire, New Jersey, New Mexico, Nevada, North Carolina, and Washington. Interview with George Kuhlman, American Bar Association (Nov. 1986), updating American Bar Association, The Status of the Model Rules in 53 Jurisdictions (Oct. 9, 1985). Lisa Milord and George Kuhlman of the ABA provided helpful assistance in locating sources and figures.

${ }^{51}$ Thomas D. Rotunda and Ronald D. Rotunda, Professional Responsibility: Problems and Materials 28 (3d ed. 1984).

${ }_{52}$ Alaska, Arizona, Arkansas, Connecticut, Delaware, Florida, Hawaii, Idaho, Illinois, Indiana, Iowa, Kentucky, Maine, Maryland, Massachusetts, Missouri, Nevada, New Hamp- 
In others, a state statute adopts the Code. ${ }^{54}$ In some states, the state bar itself formally adopts the Code, ${ }^{85}$ although in a few the state's highest court can amend or enforce it. ${ }^{56}$

Where a state adopts the Code as part of its statutory law or where the state's highest court promulgates Rules of Court and adopts the Model Code or Model Rules as such, state courts clearly have the power to enforce the rules of professional responsibility, either as state law or as Rules of Court. In some states rules established by the state supreme court have the force of law. ${ }^{57}$ In states where the highest court has not adopted the Code or Rules, the courts still enforce provisions of the Code adopted by the bar. For example, courts in such states disqualify attorneys for conflicts of interest in violation of Canon 9 of the Code of Professional Responsibility. ${ }^{58}$ Significantly, a judge's discretion is broad enough to allow him to exclude evidence when its probative value is outweighed by its potential for undue prejudice in the fact finding process. $^{59}$ Thus, it is plain that state courts have the power to en-

shire, New Mexico, Ohio, Oklahoma, Oregon, Pennsylvania, Rhode Island, South Carolina, Tennessee, Texas, Vermont, Virginia, West Virginia, Wisconsin, and with respect to the District of Columbia, the D.C. Court of Appeals. Interview with Lisa Milord, ABA Standing Comm. on Ethics and Professional Responsibility, Nov. 1985. See, e.g., Ariz. S. Ct. Rule 42 (1985); Ark. S. Ct. Rules (1985); Del. S. Ct. Rule 61 (1984); Fla. Rules of Court (1986); Ind. S. Ct. Order of Mar. 8, 1971; Iowa S. Ct. Order of Oct. 4, 1971; Ky. S. Ct. Rule 3.130 (1986); Mo. S. Ct. Rule 4 (1984); S.C. S. Ct. Rule 32 (1977); Va. S. Ct. Rule pt. 6, § II (1986); Wis. S. Ct. Rules ch. 20 (1986).

s3 Colorado, South Dakota. Interview with Lisa Milord, Nov. 1985.

${ }^{54}$ Kansas is one of these states. Id. See Kan. Stat. 7-125 (Rule 225).

${ }^{65}$ This has occurred in Connecticut, Idaho, Louisiana, Michigan, Mississippi, Nebraska, New York, North Carolina, North Dakota, and Utah. Interview with Lisa Milord, Nov. 1985.

ss Alabama and Wyoming have followed this approach. Id. See Ala. S. Ct. Rules 1, 2 (1984).

s7 See, e.g., Cunningham v. Long, 125 Me. 494, 496, 135 A. 198, 199 (1926).

ss See Gray v. State, 469 So.2d 1252, 1254-55 (Miss. 1985) (disqualifying district attorney since he had previously represented or had been consulted professionally by the accused with respect to the charges against him; citing Canons 4, 5, 9); Margulies by Margulies v. Upchurch, 696 P.2d 1195, 1202-04 (Utah 1985) (holding that conflict of interest involving representation of a limited partnership required disqualification; finding violations of Canons 4, 5 and 9); Taylor Coal Co., 401 So.2d at 7 (no violation of Canons 4 and 9 of the Code so writ directing judge to disqualify attorney denied); G.A.C. Commercial Corp. v. Mahoney Typographers, Inc., 66 Mich. App. 186, 191, 238 N.W.2d 575, 577 (1975) (disqualifying law firm for breach of Canon 9 by hiring an attorney who represented the opposing party); Brasseaux v. Girouard, 214 So.2d 401, 404-05 (La. App. 1968) (relying on Canon 6 of the ABA Canons of Professional Ethics to reverse trial court decision refusing to disqualify law firm when conflict of interest arose with client the firm formerly had represented).

s2 See, e.g., Cal. Evid. Code § 352. See also Sappenfield v. Main St. 8 A.P.R. Co., 91 Cal. 48, 61-63, 27 P. 590, 593-94 (1891), where the court required exclusion of evidence of subsequent repairs, and which was later codified in Cal. Evid. Code $\$ 1151$. Cal. Evid. Code 
force the rules through sanctions; in fact, the American Bar Association has suggested that "[u]ltimate and exclusive responsibility within a state for the structure and administration of the lawyer discipline ... system and the disposition of individual cases is within the inherent power of the highest court of the state."60

Recognizing this authority, in Bruske $v$. Arnold ${ }^{61}$ the Illinois Supreme Court upheld a trial court's exclusion of a statement given by the defendant to a private investigator hired by the plaintiff's counsel. The investigator obtained the statement after the defendant had retained counsel, and the plaintiff was aware that the defendant had counsel. ${ }^{62}$ The Illinois Supreme Court noted that the rationale proffered for admissibility was the importance of ascertaining the truth, but it held that this concern must yield to the rules of discovery and the canons of ethics: "[The r]ules, however, to be effective must carry an appropriate sanction; otherwise, the orderly process of a lawsuit is left to the mercy of the individual's sense of justice. We deem that the appropriate sanction in this instance was the exclusion from evidence of the statement." "63

2. Federal courts' powers to exclude evidence. Like state courts, federal courts have the power to regulate attorneys practicing before them. ${ }^{64}$ Federal courts may discipline attorneys who violate the rules of professional responsibility. In fact, some courts view the exercise of this power as an obligation: "A district court is obliged to take measures against unethical conduct occurring in connection with any proceeding before it."6s

$\S 1154$ (excluding evidence of settlements) and $\$ 1155$ (excluding evidence of insurance coverage) also codify judicially created exclusionary rules designed to encourage certain behavior.

Bo ABA Discipline Standards at Standard 2 (as amended) (cited in note 20).

s1 44 Ill.2d 132, 254 N.E.2d 453 (1970).

${ }^{62}$ Id. at $135-36,254$ N.E.2d at $455-56$.

ss Id.

64 E.F. Hutton \& Co. v. Brown, 305 F. Supp. 371, 378 (S.D. Tex. 1969) ("Attorneys . . who appear before a court are subject to its disciplinary power, a power which authorizes the court to regulate the practice of law both within and without the courtroom.").

${ }^{88}$ Musicus v. Westinghouse Electric Corp., 621 F.2d 742, 744 (5th Cir. 1980). See also Bohrod v. United States, 248 F. Supp. 559, 566 (W.D. Wisc. 1965) ("[T]he power of the federal courts to formulate rules of evidence is not limited to the enforcement of constitutional strictures. Evidence may be barred even though the circumstances in which it was obtained do not offend the Constitution. The federal courts have the duty of 'establishing and maintaining civilized standards of procedure and evidence." "), quoting McNabb v. United States, 318 U.S. 332, 340 (1943).

In general, federal district courts apply the Model Code or Model Rules by adopting them or incorporating them into a local rule. See, e.g., Sun Studs, Inc. v. Applied Theory Associates, Inc., 772 F.2d 1557, 1566 (Fed. Cir. 1985), in which the District Court for Oregon promulgated a local rule that substantially adopted the standards of professional conduct 
Accordingly, several federal courts in criminal cases have excluded evidence obtained in violation of the rules against communications and misrepresentation, ${ }^{66}$ and a number of decisions suggest that federal courts have the authority to exclude such evidence in civil cases as well. In Trans-Cold Express, Inc. v. Arrow Motor Transit, Inc. ${ }^{67}$ a truck accident case, the defendant's attorney employed an investigator who interviewed the father of the employee-driver of the plaintiff's truck. ${ }^{68}$ The investigator

required of members of the Oregon State Bar, and the court of appeals held that those standards governed the conduct of the district court's bar. See also Paul E. Iacono Structural Engineer, Inc. v. Humphrey, 722 F.2d 435, 438 (9th Cir. 1983), in which the Ninth Circuit upheld the disqualification of an attorney in the face of arguments that the rules of professional responsibility applicable to lawyers practicing before the district court did not include the provisions of the Model Code. The court said, "We disagree with the conclusion that to have force the Model Code must be specifically adopted," id. at 438, and noted that "[i]n the absence of rules promulgated by higher authorities in the judicial system, the district courts are free to regulate the conduct of lawyers appearing before them." Id. at 439.

Similarly, the Third Circuit applied the Model Code and Model Rules to a disqualification case where it had not expressly adopted the Code or the Rules and where disqualification was first raised on appeal. In re Corn Derivatives Antitrust Litigation, 748 F.2d 157 (3d Cir. 1984). The court in Corn Derivatives wrote:

One of the inherent powers of any federal court is the admission and discipline of attorneys practicing before it. ...

.. . Our Court of Appeals has never formally adopted any particular formulation of the standards of professional conduct. The lack of formal standards, however, cannot mean that the attorneys appearing before us do not have ethical obligations and duties. ... [T]he vast majority of courts in this country have adopted, with slight variation, the Code of Professional Responsibility promulgated by the American Bar Association, and thus, the basic principles of an attorney's duties and responsibilities are clear and easily applied. Further, since ... the attorneys . . . are bound by the duties imposed by the bars of their respective states, they have notice of the common principles against conflicts of interests imbedded in the national standards of current practice.

Id. at 160 . Hence, federal courts need not adopt local rules incorporating the Model Code or Model Rules in order to be able to apply the Code or Rules in cases of attorney misconduct, though of course such adoption would make their applicability even clearer.

* For example, see United States v. Thomas, 474 F.2d 110, 112 (10th Cir. 1973) (holding that a statement obtained by an attorney from the defendant without notifying the defendant's attorney of the interview may not be admitted as evidence); United States v. Batchelor, 484 F. Supp 812 (E.D. Pa. 1980) (granting new trial to defendant because attorney interviewed him without obtaining prior consent of defendant's counsel); United States. v. Rogers, 751 F.2d 1074, 1079 (9th Cir. 1985) (holding evidence could be excluded that was obtained through misleading and threatening statements by government attorney).

As discussed below in part III-A, the rationales for extending the rule to criminal cases are weaker than for civil cases, and therefore this comment recommends excepting criminal cases from the proposed exclusionary rule.

${ }^{67} 440$ F.2d 1216 (7th Cir. 1971).

68 Id. While the decision does not state that the investigator worked for the defendant's attorney (rather than for the defendant himself), this inference is reasonable because the court shows concern both with the deception and with the lack of notification to the plaintiff's attorney. Id. at 1218. The latter would only be relevant to an attorney's agent, 
failed to notify the plaintiff's attorney of the interview. The father believed that the investigator represented his son's employer, the plaintiff, and the investigator did nothing to dispel this impression. The trial court excluded the evidence because it had been deceptively obtained, ${ }^{69}$ and the Seventh Circuit upheld the decision, noting that "the desirability of deterring improper investigative conduct was a factor which the court could properly consider in the exercise of its discretion to exclude the evidence."

In addition, some cases have concluded that the exclusion of an attorney's work product is an appropriate sanction where the attorney has been disqualified from a case for violations of the rules of professional responsibility. In the Second Circuit case of Ceramco, Inc. v. Lee Pharmaceuticals, ${ }^{71}$ for example, the plaintiff's attorney telephoned several of the defendant's employees, who were not told the attorney's identity or purpose, and obtained nonprivileged, relevant, and accurate information concerning jurisdiction. The defendant appealed from the lower court's denial of defendant's motion to disqualify the plaintiff's attorney for his conduct. While the Second Circuit said the attorney's behavior was "not to be commended," it found the evidence did not prejudice the attorney's opponent; thus it did not disqualify the attorney's firm from the case and declined to penalize the client by "precluding reliance on counsel's work product."72 In this way, the court implied that if the improperly obtained information were sufficiently prejudicial, it could be barred from evidence or from use by

since in general there are no rules preventing non-lawyers from talking to parties absent notice to the latter's attorneys.

${ }^{69}$ See id. at 1219. The court suggested that the investigator's acts implicated the rules of professional responsibility even though the investigator was not an attorney. See id. at 1219 n.9. Such a result follows from Model Code DR 1-102, which prohibits an attorney from violating a Disciplinary Rule, circumventing a Disciplinary Rule through the actions of another, and engaging in dishonesty, fraud, deceit, or misrepresentation. Similarly, Rule 8.4 of the Model Rules declares that it is professional misconduct for a lawyer to violate or attempt to violate the rules of professional conduct, or to knowingly assist or induce another to do so, or to do so through the acts of another. Thus, both the Rules and the Code prohibit attorneys from circumventing the rules of professional responsibility through the acts of others.

70 Trans-Cold Express, 440 F.2d at 1219. Although the trial court excluded the evidence by exercising its discretion with respect to the admissibility of expert testimony, the Court of Appeals noted that the trial court's decision was based largely on its perception of unethical behavior. Id.

710 F.2d 268 (2d Cir. 1975).

72 Id. at 271. See also First Wis. Mortg. Trust v. First Wis. Corp., 584 F.2d 201, 204-05 (7th Cir. 1978) (rejecting per se rule that would exclude work product of any attorney who is disqualified for violations of the rules of ethics, but acknowledging that exclusion may be appropriate in some cases). 
those represented by the attorney.

Thus, it appears that both federal and state courts have the power to exclude evidence obtained by an attorney or his agent in violation of the rules of professional responsibility. The next section of this comment discusses the benefits to be gained from courts' exercise of their exclusionary power.

B. Benefits of Exclusion of Evidence Obtained in Violation of the Rules of Professional Responsibility

1. Deterrence. Exclusion undermines the incentives for attorneys to engage in behavior that violates the rules of professional responsibility in order to obtain evidence for their clients. Evidence obtained in violation of the rules will be excluded; therefore, it will have no value at trial and little value in settlement negotiations. The degree of deterrence depends, as a first approximation, on the ratio between the expected cost of being detected (the probability of detection multiplied by the cost of detection) and the value of the evidence improperly obtained. Under an exclusionary rule, the cost of being detected is the value of the evidence excluded. An exclusionary rule may not be a perfect deterrent, since the probability of detection is less than 1 ; but the rule can significantly reduce incentives to misbehave, since the cost of exclusion may be much higher than the cost of suffering sanctions for misconduct, and, more importantly, because the probability of detection should increase a great deal when opposing attorneys can benefit from reporting violations that result in exclusion of evidence.

Exclusion of evidence has been recognized as an appropriate means of deterring improper conduct. ${ }^{73}$ In fourth amendment cases, the Supreme Court has recognized deterrence of illegal police conduct as a legitimate rationale for excluding evidence that has been unconstitutionally obtained: "[T] he [exclusionary] rule is calculated to prevent. . . . Its purpose is to deter-to compel respect for the constitutional guaranty in the only effectively available way-by removing the incentive to disregard it."74 The Court

${ }^{73}$ See, e.g., Trans-Cold Express, 440 F.2d at 1219 ("Entirely apart from the possible probative value of the statement, the desirability of deterring improper investigative conduct was a factor which the court could properly consider in the exercise of its discretion to exclude the evidence.").

${ }^{74}$ Elkins, 364 U.S. at 217; Terry, 392 U.S. at 12 ("Ever since its inception, the rule excluding evidence seized in violation of the Fourth Amendment has been recognized as a principal mode of discouraging lawless police conduct."). 
has accepted deterrence as a legitimate rationale in the constitutional cases because no other effective method of protecting the relevant constitutional rights exists. ${ }^{75}$ Similarly, given the ineffective alternatives to exclusion in enforcing the rules of professional responsibility (discussed in part II-D below) and the importance of deterring conduct that violates these rules, an exclusionary rule seems justified.

In fact, the likelihood that the rule will deter unethical conduct by attorneys is far greater than the likelihood that an exclusionary rule will deter improper police conduct. In the context of professional responsibility, the rule operates directly on the attorney violating the rule by damaging his case and affecting his livelihood; in contrast, it is highly questionable whether a police officer has sufficient interest in the outcome of a criminal trial that the prospect of exclusion will influence his behavior. ${ }^{76}$

Adopting the exclusionary rule in the professional responsibil-

${ }_{75}$ Mapp, 367 U.S. at 652-53. See also People v. Cahan, 44 Cal.2d 434, 445, 282 P.2d 905, 911-12 (1955). A damage action against the police for violations of fourth amendment rights, for example, has been viewed as an insufficient deterrent because many victims could not bear the burden of initiating such proceedings and because individual officers would probably not have to pay the damages in any case because the state would indemnify them. See Wayne F. LaFave and Jerold H. Israel, Criminal Procedure § 3.1(c) at 81 (one-vol. ed. 1985). The same arguments suggest that it would be insufficient to give the party harmed by a violation of the rules of professional responsibility a damage action against the culpable attorney. While the attorney might not be able to pass liability to his employer as a police officer could, a civil litigant would likely be no more able than a criminal defendant to shoulder the burdens of initiating and pursuing a separate action for misrepresentation or overreaching. Further, the Model Rules specifically state that the Rules are not to be used as a source of civil liability. Model Rules Scope [6].

${ }^{78}$ Consider, for example, Chief Justice Burger's criticisms of the exclusionary rule in Stone, 428 U.S. at 498-500 (concurring opinion), questioning whether the rule's use in criminal cases in fact deters, since it does not directly sanction the police officer for his violation of the Constitution.

The recognition that deterrence increases when a violator has a greater interest in the outcome of the proceedings finds support in a line of Supreme Court cases involving the use of unconstitutionally obtained evidence in proceedings other than criminal trials. In these cases, the Court has developed a "zone of primary interest" test to measure whether exclusion of the evidence is sufficiently likely to deter future police violations to justify applying the exclusionary rule. If the proceeding falls within "the offending officer's zone of primary interest," the Court will conclude that the police would be sufficiently deterred from future violations, and it will exclude the evidence. See, e.g., United States v. Janis, 428 U.S. 433, 458 (1976) (holding that IRS assessment was outside "zone of primary interest" of city police officer who turned over records seized in gambling raid to IRS); INS v. Lopez-Mendoza, 468 U.S. 1032, 1053 (1984) (White, J., dissenting) (arguing that evidence unconstitutionally seized by immigration officers should be excluded in civil deportation hearing since deportation is within officers' zone of primary interest). Under this test, evidence improperly obtained by an attorney surely should be excluded: a lawyer's livelihood depends on his success in trials, so exclusion of evidence improperly obtained will substantially reduce his incentive to act improperly. 
ity context will have another strong deterrent effect: the rule will create incentives for attorneys to identify and report violations by other attorneys. A major problem with the current system of disciplinary enforcement, as noted previously, is the lack of incentives to discover and report violations of the rules. The opportunity to argue for exclusion of evidence obtained in violation of the rules against communication and misrepresentation will be beneficial to the attorney's client because it may be used to eliminate evidence unfavorable to the client. Hence, the rule will create considerable incentives for attorneys to self-police within the adversarial process, since direct benefits to themselves and their clients may result if they identify and report violations. Unlike the current system, the exclusionary rule will facilitate self-regulation by attorneys, since under it violations of the rules of professional responsibility will be more likely to be discovered and the expected cost of such violations would be greater than the minimal sanctions now imposed.

2. Judicial Integrity. A second rationale for excluding evidence obtained in violation of the rules of professional responsibility is that by admitting such evidence, a court participates in the improper behavior and in effect condones it. This brings the court and the judicial system into disrepute. The rationale has been used to justify the exclusionary rule for constitutional violations: "When ... the very purpose of an illegal search and seizure is to get evidence to introduce at a trial, the success of the lawless venture depends entirely on the court's lending its aid by allowing the evidence to be introduced." tions of the rules of professional responsibility: unless the court lends its aid by allowing the introduction of evidence procured in violation of the rules, the improper behavior will be completely unsuccessful. If the court allows the introduction of the evidence, the court, as well as the attorney, may be publicly perceived as unfair and unjust.

Admittedly, judicial sanctioning of unconstitutional acts is more serious than judicial sanctioning of professional violations. Nevertheless, state supreme courts and the federal courts are responsible for disciplining attorneys, and they should not reward behavior that violates the rules by admitting its fruits as evidence in the courtroom. In response to such admission, the public is likely to hold the courts responsible for the unfairness of a system 
that condones such behavior. By forbidding the use of evidence obtained in violation of the rules in their courtrooms, judges prevent the deterioration of public respect for the courts.

\section{Costs of the Exclusionary Rule}

The exclusionary rule's benefits of deterring attorney misconduct, encouraging self-policing, and helping maintain judicial integrity must be weighed against the rule's costs. The primary cost of exclusion of evidence obtained by violating the rules is that it removes probative evidence from the court and jury. ${ }^{78}$ This may be a significant cost, for exclusion may interfere with a central function of trials: to ascertain the truth. In some cases, the consequence of exclusion will be severe: a wrong decision will be reached because part of the truth is kept from the finder of fact.

But one should not overestimate the loss in probative evidence that will result from an exclusionary rule. As argued above in part $\mathrm{I}-\mathrm{C}$, there are strong reasons to think that statements a person makes without knowing the listener is an attorney, or on the basis of misrepresentations by the attorney, will tend to be unreliable. ${ }^{79}$ The person may not be as careful in exercising his memory or narrating his story as he would be if the attorney has made his identity known; and it is unclear whether knowing one is speaking to an opposing attorney increases or decreases one's sincerity. In some ways, therefore, the exclusion of evidence obtained in violation of the rules of professional responsibility does not suffer from one of the defects of the exclusion of evidence obtained in violation of the rights of criminal defendants: namely, barring highly probative evidence. In fact, the rule in the professional responsibility context can act in concert with the hearsay rule to screen a class of evidence of questionable reliability. ${ }^{80}$

Moreover, whatever costs there are should be short-lived. As it

${ }^{38}$ Exclusion may impede truthfinding, Leon, 468 U.S. at 906-07, by denying the jury reliable and probative evidence, Stone, 428 U.S. at 489-90.

79 See note 42 above and text accompanying and following.

so One might argue that some of the constitutional prohibitions-against confessions or identifications obtained without counsel, at least-rest on a judgment that such tactics will produce results of questionable validity. Wade, 388 U.S. at 228-32. But Miranda did not single out only those confessions likely to be false. See 384 U.S. at 436. And in the search and seizure context, where the exclusionary rule has received the most criticism, it is clear that the violation does not undercut the reliability of the evidence. Indeed, one of the major criticisms of the rule is that it will prevent highly probative evidence from coming to the attention of the fact finder, thus allowing a guilty criminal to go free. See note 78 and accompanying text above. 
becomes clear to attorneys that evidence obtained through violations of the rules of professional responsibility will be excluded, and as increased self-policing renders the likelihood of detection high, most attorneys will be motivated to obtain evidence through proper channels. Hence, even if the short-term costs in reduced accuracy are substantial, in the long run the costs should be minimal because attorneys will adjust their behavior to the new exclusionary rule.

On the other hand, if courts fail to provide disincentives and continue to admit evidence obtained by improper shortcuts, the incidence of such improper conduct will probably remain high. By allowing attorneys to violate the rules without suffering sanctions, the courts give the parties represented by attorneys who misbehave an advantage over those whose attorneys obey the rules. ${ }^{81} \mathrm{Re}$ acting to this unfair advantage, even the responsible lawyer may be tempted to violate the rules in order to neutralize his opponent's use of evidence obtained through violation of the rules. Thus, unless such evidence is excluded or some alternative disincentive to violating the rules is provided, the advantages of obtaining evidence through rules violations will encourage violations.

Of course, adopting an exclusionary rule may result in harm to the attorney's client-who may be completely unaware of the attorney's misbehavior and may not in any way have approved of it. The client may be substantially worse off because of the exclusion of the evidence, through no apparent fault or misbehavior of his own. At first glance, exclusion thus seems to impose an unjust penalty on the misbehaving attorney's client. But, emphasizing the agency relationship between client and attorney, the Supreme Court has rejected such an argument under the more serious circumstance of dismissal of the cause of action due to an attorney's conduct:

There is certainly no merit to the contention that dismissal of petitioner's claim because of his counsel's unexcused conduct imposes an unjust penalty on the client. Petitioner voluntarily chose this attorney as his representative in the action, and he cannot now avoid the consequences of the acts or omissions of this freely selected agent. ${ }^{82}$

The question is really which of two innocent parties should bear the loss from conduct that violates the rules. Since the party 
whose attorney improperly obtained evidence freely chose that attorney, it seems more just to impose the costs on him. He should suffer the consequences of his attorney's actions, rather than the opposing party who did not choose the misbehaving attorney as his representative. Such a rule also places on the party relatively more capable of preventing the improper behavior an incentive to do so: the client can be careful to retain a scrupulous attorney and to ensure that the attorney he retains remains scrupulous.

Furthermore, exclusion of evidence has less severe effects on the client than other sanctions that could be and have been imposed, such as disqualifying the attorney. ${ }^{83}$ In some cases, where the evidence could not have been obtained without violating the rules of professional responsibility, the attorney's client is in the same position he would have been in had his attorney not broken the rules: he simply is unable to make use of evidence that he had no right to obtain in the first place. ${ }^{84}$ Finally, the client can sue the attorney for malpractice if exclusion of the evidence caused a less favorable result in the case. ${ }^{85}$

An additional cost is that the rule could be used as a litigation tactic to harass opposing counsel, as many discovery rules currently are used..$^{86}$ Simply alleging that evidence has been obtained

${ }^{83}$ See Ceramco, 510 F.2d at 271 (indicating that disqualification is an alternative).

84 See Nix v. Williams, 467 U.S. 431,443 (1984), where the Supreme Court justified the independent source exception to the exclusionary rule (discussed below in notes 98-99 and accompanying text) on the ground that "the interest of society in deterring unlawful police conduct and the public interest in having juries receive all probative evidence of a crime are properly balanced by putting the police in the same, not a worse, position than they would have been in if no police error or misconduct had occurred."

8s The threat of being sued for malpractice should act as a powerful incentive for the attorney not to violate the rules of professional responsibility when an exclusionary sanction is in force, since the attorney will have to pay the costs of defending himself against a malpractice suit and, if he loses, may be liable for the value of his client's suit. It is true that the probability of losing the malpractice suit will be small, because in order to prove malpractice the client will have to demonstrate that the attorney did not exercise reasonable care in his handling of the case or did not possess or use the minimum special knowledge and ability of an attorney. W. Page Keeton, Dan B. Dobbs, Robert E. Keeton, and David G. Owen, Prosser \& Keeton on the Law of Torts 185-86 (5th ed. 1984). Since the cause of action is essentially negligence, the client, in addition, will have to show that this failure by his attorney, leading to the exclusion of material evidence, proximately caused the harm (the loss of the lawsuit, or a less favorable settlement).

Nevertheless, although the risk of loss is slight, the amount of money at stake will often be quite large, making the potential cost significant, and thus the threat of suit should pose a substantial deterrent. Aside from the costs of the suit and the possibility of liability, malpractice suits damage the attorney's reputation, injuring his future business.

${ }^{86}$ Examples of such abusive discovery tactics include huge requests for documents and endless interrogatories. See Federal Judicial Center, Survey of Literature on Discovery from 1970 to the Present: Expressed Dissatisfactions and Proposed Reforms 23, 49, 52-53, 67 
by violating the rules would provide an effective delaying tactic by requiring inquiry into the method of obtainment. Further, the accusation may bring an attorney into disrepute, and it likely will embarrass him in front of his client. To counter this problem, courts could impose fines or other sanctions for falsely alleging improper behavior when there is no basis for the allegations. ${ }^{87}$ Such fines or sanctions may be only seldom imposed, but the threat of sanctions together with the injury to attorneys' relations with colleagues may be sufficient to prevent many attorneys from making false allegations.

A final disadvantage of the exclusionary rule is that its application may be uncertain and vague. There will be difficult cases where it is unclear whether an attorney has in fact violated the rules, and it may be difficult in some circumstances for attorneys to determine beforehand whether their planned conduct will violate the rules. For example, in negotiations the line between actual misrepresentation and puffing is very thin and thus difficult to draw. Nevertheless, there will be many easy cases in which the rule can be enforced with little uncertainty, as for example when an attorney talks to the opposing party without informing the party's counsel. Furthermore, courts enforce many rules where the result in all cases is not clear in advance. As courts begin to enforce the rule, the common law will develop and uncertainty as to the exclusionary rule's parameters will diminish. ${ }^{88}$

Overall, the rule's benefits-deterring violations of the rules of professional responsibility, encouraging self-policing of such violations, and preserving judicial integrity-appear to outweigh its costs. Moreover, exclusion is preferable to suggested alternative sanctions, as discussed below. Furthermore, the costs of the rule

(1978).

The Model Rules expressly prohibit counsel from using the Rules as a tactical weapon in litigation. Model Rules Scope [6]. Surely this does not mean, however, that attorneys may not request, and courts may not grant, sanctions for violations of the Rules that will have a strategic effect on pending litigation. For example, the courts disqualify attorneys for violations of the Rules without questioning whether this sanction itself violates this provision of the Rules. See notes 93-96 and accompanying text below. Yet disqualification certainly may delay litigation and impede the cause of the client whose attorney has been disqualified. There is no reason to assume that the proposed exclusionary rule has a greater potential for tactical abuse by attorneys than does the power to disqualify.

*7 The courts clearly would have such power under the provisions of Fed. Rule Civil Proc. 11 and analogous state rules.

so Compare Judge Easterbrook's comment on the development of fourth amendment case law in Gumz v. Morrisette, 772 F.2d 1395, 1407 (7th Cir. 1985) (concurring opinion) ("There is now a tremendous body of precedent dealing with searches and seizures, and these cases furnish rules that ought to be sufficient guidance in a case such as this."). 
may be mitigated by carving out the exceptions discussed in part III-A.

\section{The Inadequate Alternatives to Exclusion}

The two main alternatives to the exclusionary rule, citation for contempt and disqualification, are both inferior. The ABA has argued that conduct that violates some of the rules of professional responsibility may constitute contempt," noting that "the contempt power is directed toward acts which threaten to obstruct justice . . . or toward acts which tend to bring the court into disrepute." ${ }^{\text {" Hoo }}$ Hover, there are several reasons why contempt citation of attorneys who seek to introduce evidence obtained in violation of the rules of professional responsibility is inappropriate.

First, courts have been reluctant to use their contempt power to attack conduct that is not a direct affront to the court. While violation of the Model Code or Rules tends to lessen judicial integrity generally, the contempt sanction usually is reserved for conduct that "directly tend[s] to bring the court into disrepute." The courts have generally been unwilling to exercise their contempt power unless faced with conduct such as disobeying a judicial order or creating a disturbance in court. Judicial integrity is undermined when a court effectively condones violations of the rules of professional responsibility by failing to provide meaningful sanctions for them; but the violations themselves do not constitute a direct affront to the authority of the court.

Even if courts are willing to use their contempt power in response to "indirect" threats to their integrity, citation for contempt probably will not be an effective deterrent. Although the cost to the attorney held in contempt might be substantial, the likelihood of detection and punishment by citation is substantially less than under an exclusionary rule. ${ }^{92}$ Therefore, the contempt citation seems to be both a less likely and a less effective mechanism for remedying violations of the rules of professional responsibility than is the proposed exclusionary rule.

A second alternative to exclusion is disqualification of the offending attorney from the case. ${ }^{93}$ This alternative would deter at-

89 ABA Standing Comm. on Professional Discipline and the Center for Professional Responsibility, The Judicial Response to Lawyer Misconduct V.4 (1984).

${ }^{80}$ Id. at VI.3.

91 Id. at VI.5 (emphasis added).

${ }^{22}$ See note 76 above and text accompanying and following.

${ }^{93}$ See Ceramco, 510 F.2d at 271. 
torneys from violations of the rules, since an attorney could not reap the benefits of his work through charges to his client once he had been disqualified. In addition, disqualification might create a sufficient incentive for opposing counsel to uncover and disclose the violation, since the result would be that the attorney's client will find himself without counsel at what may be a critical stage in the litigation. But this is a rather harsh response, for it deprives the attorney's client of his choice of counsel, in which he has a substantial interest: ${ }^{94}$ certainly greater in general than the interest in having a particular piece of evidence admitted.

In addition, disqualification is the appropriate remedy only where a conflict of interest exists "such that continued representation by chosen counsel clearly prejudice[s] the rights of the opposing party." Disqualification in such a case prevents the conflict of interest that results when an attorney represents one party to litigation when he has a prior relation with the opposing party. In contrast, when evidence is obtained by violating the rules of professional responsibility, the issue focuses not on the attorney but on the evidence. The analogue to excluding (disqualifying) the improperly retained attorney from the case is excluding the improperly obtained evidence from the case. Finally, if the only remedy is to disqualify the attorney who improperly obtains evidence, the new attorney may still be able to use the evidence, and the opposing party will have suffered the same harm. Hence, disqualification, like disciplinary proceedings and contempt, is a less appropriate and less effective remedy than exclusion. ${ }^{96}$

94 While parties do not have an absolute right to the counsel of their choice, see Richardson-Merrell, Inc. v. Koller, $105 \mathrm{~S}$. Ct. 2757 (1985) (counsel disqualified for misconduct), they do have a substantial interest in choosing their own counsel. See Cossette v. Country Style Donuts, Inc., 647 F.2d 526, 530 (5th Cir. 1981); In re Northern Dist. of Cal., Dalkon Shield, etc., 693 F.2d 847, 851 (9th Cir. 1982) ("[T]he right of litigants to choose their own counsel is a right not lightly to be brushed aside.").

Federal courts have applied the qualified right to counsel of one's choice, found in the sixth amendment, to civil cases. For example, in In re American Cable Publications, Inc., 768 F.2d 1194 (10th Cir. 1985), a contract dispute involved an attorney, Frascona, who was a defendant and third-party plaintiff, and who hired his law partner to represent him. An opposing party sought to have Frascona's attorney disqualified on the grounds of violation of DR 5-101(B). The court found DR 5-101(B) not to preclude such representation, since the law partner would not act as a witness in the case. The court stated: "We believe that important Sixth Amendment right to counsel principles are at issue in this situation. Frascona has an unquestioned right to self-representation. See 28 U.S.C. $\$ 1654$. A corollary to that right is the right of representation by counsel of his choosing." Id. at 1196. See also Bottaro v. Hatton Associates, 680 F.2d 895, 897 (2d Cir. 1982) (right to counsel of one's choice "can be overridden only where compelling reasons exist").

${ }^{95}$ Ceramco, 510 F.2d at 271.

${ }^{88}$ Likewise, fines or suspensions that do not impede the attorney's performance in the 


\section{IMPLEMENTING THE EXCLUSION OF IMPROPERLy ObTAINED Evidence}

\section{A. The Exclusionary Rule in Practice: Three Exceptions}

One can limit the costs from exclusion of evidence by implementing three exceptions to the proposed exclusionary rule. The first two exceptions, the "independent source" exception and the inevitable discovery exception, are modeled after the exceptions to the exclusionary rules for constitutional violations. ${ }^{97}$ The third exception, limiting application of the proposed exclusionary rule to civil cases only, is based on the practical recognition that the costs may outweigh the benefits of this exclusionary rule in criminal cases.

The first, the "independent source" exception, was originally announced by the Supreme Court in Silverthorne Lumber Co., Inc. $v$. United States, ${ }^{98}$ a case involving an unconstitutional seizure. The "independent source" exception provides that evidence obtained improperly may not be used at all, but the facts obtained through that evidence are not "sacred and inaccessible. If knowledge of them is gained from an independent source they may be proved like any others. . . ."99 The Silverthorne rule leaves the prosecutor no worse off than if the illegal search had not occurred-he has only the facts and evidence legally obtained-but the illegal search does not limit the use of legitimately obtained evidence. If facts are provable independent of the evidence obtained in violation of the rules of professional responsibility, the legitimately obtained facts should be admitted. The opposing party is not unfairly harmed or prejudiced by admission of these facts into evidence, since they were not wrongfully acquired and would have been available and admissible had no improper behav-

case at hand are not adequate deterrents, as they create little incentive for disclosure of the violation by opposing counsel.

97 Another possible exception would allow admission of improperly obtained statements for the purposes of impeachment. The Supreme Court has upheld admission into evidence of statements unconstitutionally obtained from a defendant when the defendant affirmatively resorted "to perjurious testimony in reliance on the Government's disability to challenge his credibility." Walder v. United States, 347 U.S. 62, 65 (1953).

${ }^{83} 251$ U.S. 385, 392 (1920). The Court held that unconstitutionally seized books and papers (obtained without a warrant) could not be subpoenaed for the grand jury, nor could photos of them be used to obtain knowledge upon which to frame a subpoena. The contents of the papers were constitutionally protected, but the government could use those contents if it obtained them from a source independent of the illegal search.

${ }^{98}$ Id. at 392. See also Bynum v. United States, 274 F.2d 767, 767 (D.C. Cir. 1960) (per curiam). 
ior occurred.

A second applicable exception is the "inevitable" or "ultimate discovery" exception, adopted by the Supreme Court in Nix $v$. Williams. ${ }^{100}$ Under this exception, if the party opposing exclusion "can establish by a preponderance of the evidence that the information ultimately or inevitably would have been discovered by lawful means ... then the deterrence rationale has so little basis that the evidence should be received."101 The exception is particularly applicable to physical evidence, the location of which is unknown. Nix involved the missing body of a homicide victim, which would have been found by a search party looking nearby had the defendant not told the police its location.

In applying the "inevitable discovery" exception to violations of the rules of professional responsibility, courts should draw a distinction between statements and physical evidence, applying the exception with regard to the latter but not the former. The exception should not apply to statements since it is almost impossible to demonstrate that a statement would "inevitably" have been discovered in the exact same form if the attorney had complied with the rules; as noted in part I-C, a person's statements may differ depending on whether he knows that the person to whom he is talking is an attorney. Thus, such evidence should be excluded. Further, it would be difficult to prove that the "facts" presented by those statements would inevitably have been discovered absent attorney misbehavior. Where the facts might be discovered through means complying with the rules, the violation of the rules often constitutes a shortcut that saves the attorney (and client) time and money. If courts admitted such evidence on the ground that it would inevitably have been discovered, they would encourage the taking of shortcuts that violate the rules of professional responsibility. Hence, where the improperly obtained evidence is a statement, this exception should not be allowed. Where the evidence is physical, the court should admit it but only after examining carefully whether the evidence truly would "inevitably" have been found.

The third exception to the proposed exclusionary rule is that exclusion would not be required in criminal cases. While the proposed rule of exclusion could be applied in criminal cases, this comment argues against such extension for several reasons. First, the controversy surrounding the exclusionary rule for constitu- 
tional violations in criminal cases indicates that the social costs of exclusion are very great in criminal cases. ${ }^{102}$ Since guilty defendants may go free as a result of exclusion in criminal cases, the balancing of costs and benefits of the rule weighs less strongly in favor of the rule. ${ }^{103}$ The freeing of some criminals is more likely to produce general disrespect for the law-indeed, to undermine the very notion of "judicial integrity" that the exclusionary rule is supposed to serve ${ }^{104}$ - than is the use of such rules in civil cases, where at worst exclusion will allow some tortfeasors to avoid paying for their non-criminal torts. Arguably, these tortfeasors incur sufficient penalties for their conduct simply by going to trial. The public is more likely to be upset by the spectre of unpunished criminals running rampant in society than by the knowledge that some tortfeasors escape paying damages. However rational or irrational this public opinion of the judicial system, it is a factor that the exclusionary rule takes into account under the rubric of "judicial integrity." 105

Second, not only will the costs of each inaccurate result be greater in criminal cases (a free criminal versus a liability-free tortfeasor), but it is more likely that an inaccurate result will follow in criminal cases from exclusion of a given piece of evidence. This is because the burden of proof necessary to establish liability is greater in criminal cases-beyond a reasonable doubt, as opposed to the preponderance of the evidence. The corollary of that standard is that a criminal defendant need create fewer doubts than a civil defendant in order to escape liability. Thus the importance of each piece of evidence is magnified.

Third, exclusion of unethically obtained evidence may have less of an incentive effect on the attorneys in criminal cases. ${ }^{106}$ Contingency fee lawyers, who handle a significant percentage of

102 For general discussion of the criticism of the exclusionary rule as socially costly, see Wayne R. LaFave and Jerold H. Israel, 1 Criminal Procedure at 136-41 (1984). For example, consider the argument that the exclusionary rule in criminal cases leads to a general disrespect for the law and the administration of justice because it provides the "spectacle of courts letting the guilty go free," Dallin H. Oaks, 37 U. Chi. L. Rev. 665, 737 (1970), quoting Monrad Paulsen, The Exclusionary Rule and Misconduct by the Police, 52 J. Crim. L.C. \& P.S. 255, 257 (1961). See also Stone, 428 U.S. at 491.

${ }^{103}$ Bivens v. Six Unknown Fed. Narcotics Agents, 403 U.S. 388, 413 (Burger, C.J., dissenting).

104 See part II-B-2 above, discussing the exclusionary rule's role in protecting judicial integrity.

105 See id.

106 Compare note 76 and accompanying text above, arguing that while incentives created by exclusion due to violations of the rules of professional responsibility are clear as to attorneys, incentives to police officers in constitutional cases are highly questionable. 
civil cases, collect no money if they lose. No such direct financial risk operates on the government lawyer in criminal cases. Of course, there are deterrents to poor performance by government lawyers as well, but a line between civil and criminal cases represents a first approximation of the likely deterrent effects of the rule in an individual case. The administrative costs of finding a perfect "fit" (i.e., tailoring the rule only to specific cases in which it is likely to deter) would likely overwhelm its benefits.

Fourth, application of the rule to criminal cases could, in effect, result in a requirement that counsel must be present in order for a party to waive counsel once the sixth amendment right to counsel has attached. This is because the prosecutorial authorities would be unable to speak with the accused, even if the accused initiated the communication, without informing his attorney in advance and allowing him to be present. To date, the Supreme Court has specifically declined to rule that a waiver of the right to counsel cannot be made absent counsel. ${ }^{107}$

Finally, it should be noted that several courts already have ruled on whether to exclude evidence in criminal cases obtained by violating the rules of professional responsibility. In general, state courts have ruled against excluding the evidence. ${ }^{108}$ Federal courts have looked with more favor on the remedy of exclusion in criminal cases. ${ }^{109}$ Given the controversial nature of applying the proposed exclusionary rule in criminal cases, this comment suggests that the rule be limited to civil cases, where the rule's benefits more clearly outweigh its costs.

\section{B. The Scope of the Exclusion: Fruit of the Poisonous Tree}

A final, key issue in applying this rule will be determining the scope of exclusion. For example, in the hypothetical described in

${ }^{107}$ Oregon v. Bradshaw, 462 U.S. 1039, 1044-46 (1982); Edwards v. Arizona, 451 U.S. 477, 483-85 (1980); Brewer v. Williams, 430 U.S. 387, 405-06, 413 (1977).

${ }^{108}$ For example, in People v. Green, 405 Mich. 273, 274 N.W.2d 448 (1979), the Michigan Supreme Court refused to reverse a conviction or require a new trial where the trial court had admitted evidence of a conversation between the prosecutor and the defendant initiated at the defendant's request, but without the prior consent of the defendant's lawyer. The court held that the defendant had "knowingly and understandingly" waived his right to an attorney. 274 N.W.2d at 454. See also Lofton v. State, 471 So.2d 665 (Fla. App. 1985) (same); Pannell v. State, 666 S.W.2d 96 (Tex. Crim. App. 1984).

109 In Thomas, 474 F.2d at 112, the Tenth Circuit held that a statement obtained by an attorney from the defendant without notifying the defendant's attorney of the interview may not be offered into evidence (although the court refused to reverse the result in this case, since the rule was first being announced). See also Rogers, 751 F.2d at 1079; Batchelor, 484 F. Supp. at 813. 
part I-A, the exclusionary rule prevents the use in court of the statement of the Inventor. Whether the scope of the rule should extend to exclude information in the statement itself is unclear. For example, if the Inventor gave the name of a person, previously unknown, who also worked in the production of the widgets, and Attorney then went and interviewed him (after giving notice to Counsel, pursuant to the rules of professional responsibility), would the identity of this person and his statement be admissible? The Supreme Court, in constitutional exclusionary cases, has held such evidence inadmissible. In Silverthorne, ${ }^{110}$ the Court held invalid a subpoena issued on the basis of information acquired through an illegal search. The illegally obtained evidence could not be used directly, and hence, according to the Court, it also could not be used indirectly. The Court held that the exclusionary rule extended to all evidence derived from the unconstitutional search, including evidence subsequently obtained through the use of the information acquired during the search. ${ }^{111}$ Courts have referred to this derivative evidence as the "fruit of the poisonous tree."112

Fruit of the poisonous tree should also be excluded where the evidence has been obtained by violating the rules of professional responsibility, since allowing some uses of the evidence will substantially weaken the deterrent effect of the exclusionary rule. For example, in the case described above, in the absence of a broad exclusionary rule barring derivative evidence, Attorney could subsequently depose Inventor, as well as the third witness, and would derive all the benefits of his violations of the rules. He therefore would not be deterred from repeating such behavior. As noted by the Supreme Court, "[t]he essence of a provision forbidding the acquisition of evidence in a certain way is not that merely evidence so acquired shall not be used before the Court but that it shall not be used at all."113 The purpose of an exclusionary rule is to prevent the misbehaving party from benefiting from his misbehavior. To accomplish this goal effectively, the rule must exclude all the illgotten gains from that misbehavior. ${ }^{134}$

110251 U.S. at 385.

111 Id. at 392.

112 On excluding this evidence, see Wong Sun v. United States, 371 U.S. 471, 477-78 (1963); Harrison v. United States, 392 U.S. 219, 222 (1968); Nardone v. United States, 308 U.S. 338, 341 (1939).

${ }_{133}$ Silverthorne, 251 U.S. at 392.

114 It should be noted that excluding this derivative evidence will reduce the clarity of the exclusionary rule: there will always be hard cases, no matter where the courts draw the line of inadmissibility. This lack of clarity leads to uncertainty and is a cost of any exclusionary rule. 


\section{CONCLUSION}

Courts should adopt a rule excluding evidence obtained by violating the rules of professional responsibility. They have the power to adopt such a rule, and by doing so they will deter improper behavior, create incentives for attorneys themselves to police the rules, and protect the integrity of the judicial process. Alternative methods of deterring misbehavior and remedying its harms are ineffective: disciplinary proceedings are expensive, occur rarely, and even more rarely impose significant sanctions; citations for contempt and disqualifications of attorneys are inappropriate and may be less effective than exclusion. A rule of exclusion likely would lead to increased compliance with the two rules of professional responsibility discussed herein and would provide a means for the courts to help enforce appropriate standards of professional conduct. Adoption of such a rule would be a substantial improvement over the status quo, under which no effective sanction against such behavior exists.

The legal profession prides itself on its ability to regulate itself; it should not allow self-regulation to become synonymous with an absence of enforcement of its own rules. The Model Code of Professional Responsibility and the Model Rules of Professional Conduct should not be mere words on paper. To be effective, rules for self-regulation must be accompanied by workable and commensurate sanctions to enforce them. An exclusionary rule is such a sanction.

Erica M. Landsberg 